\title{
Slečeva rja, Chrysomyxa rhododendri
}

\section{Nikica OGRIS, Dušan JURC}

Letos smo zabeležili izredno obsežen pojav slečeve rje na severnem pobočju Kriške gore pri Tržiču. Na približno 100 ha je zelo močno poškodovala letošnje iglice mladja navadne smreke in spodnjih vej odraslih dreves. Tudi do $100 \%$ letošnjih iglic je porumenelih in bodo kmalu pričele odpadati (slika 1).

Gliva Chrysomyxa rhododendri (slovensko slečeva rja) lahko povzroča obsežne in močne okužbe v sestojih smreke, kadar sta izpolnjena dva pogoja: 1. v bližini sestoja smreke ali v podrasti raste dlakavi sleč (Rhododendron hirsutum) ali rjasti sleč ( $R$. ferrugineum) in 2 . ob odganjanju iglic so dolga obdobja vlažnega, deževnega vremena. Slečeva rja je pri nas že dolgo znana iz alpskih predelov, npr. večkrat se je že pojavila na Pokljuki in Jelovici.

Osnovne znake za slečevo rjo lahko opazimo sami na terenu, to so: porumenele letošnje iglice (slika 1) in beli mešički, ki izraščajo iz iglic (slika 2). Vendar je za potrditev glive Chrysomyxa rhododendri potrebno mikroskopirati vzorce, kajti možne so zamenjave z drugimi glivami iz rodu Chrysomyxa. Beli mešički, ki jih opazimo na porumenelih iglicah so trosišča, ki jih imenujemo eciji. Eciji so lahko dolgi tudi do $3 \mathrm{~mm}$

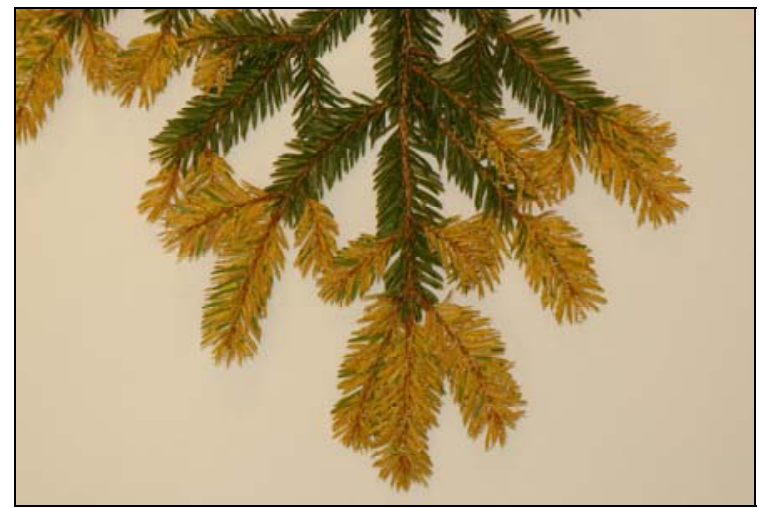

Slika 1: Letošnje iglice so porumenele; porumenelih je tudi do $100 \%$ letošnjih iglic; porumenele iglice odpadajo

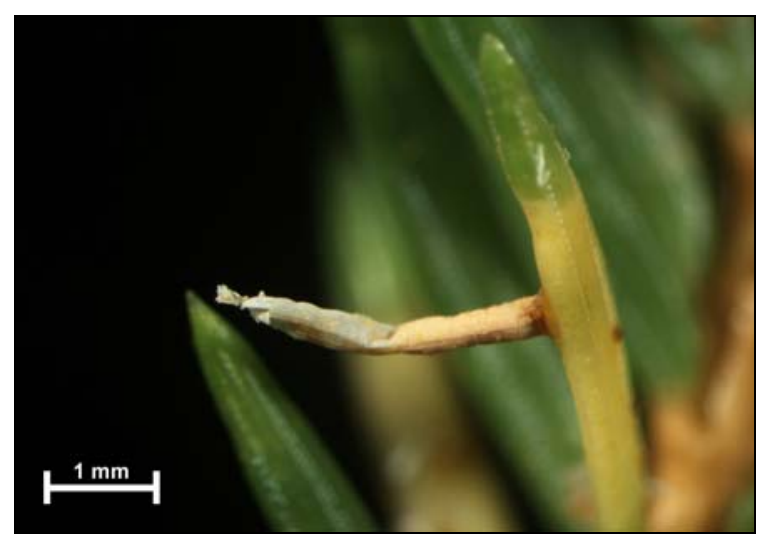

Slika 3: Eciji so lahko dolgi tudi do $3 \mathrm{~mm}$, njihov ovoj, t. j. psevdoperidij, je bele barve in se po sprostitvi trosov raztrga (slika 3). Ovoj ali psevdoperidij ecija je bele barve, je nežen in se $\mathrm{v}$ starosti raztrga. $\mathrm{V}$ ecijih se oblikujejo eciospore, ki so okrogle do elipsaste oblike, svetlo oranžne notranjosti in $\mathrm{z}$ brezbarvno bradavičasto steno (slika 4). Eciospore prenaša veter na liste dlakavega ali rjastega sleča. Tam gliva povzroča manj opazne poškodbe - svetlejše pege na listih.

Slečeva rja je dvodomna rja. To pomeni, da sta za njen razvoj potrebna dva gostitelja, t. j. navadna smre$\mathrm{ka}$ in dlakavi ali rjasti sleč. Izmenjava gostiteljev je za okužbo smreke obligatna, kar pomeni, da rja brez sleča ne bi mogla okužiti smreke. Razvojni krog je zapleten, saj se sestoji iz pet vrst različnih trosišč. Glavni prenašalec trosov je veter.

Slečeva rja je škodljiva zato, kjer povzroča poškodbe letošnjih iglic. t. j. porumenele iglice prezgodaj odpadejo in zato nekoliko prizadene prirastek. Bolezen ne povzroča odmiranje poganjkov ali celih dreves. Naslednje leto poškodovane veje ponovno odženejo.

Zatiranja bolezni v naravnem okolju ne izvajamo, saj slečev ni možno izkoreniniti, poleg tega pa so še zaščiteni.

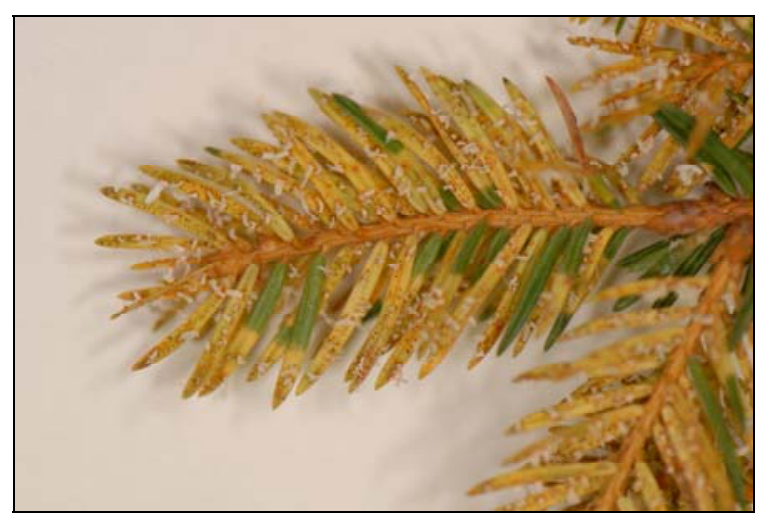

Slika 2: Na porumenelih iglicah so beli mešički; to so eciji, v katerih nastajajo eciospore

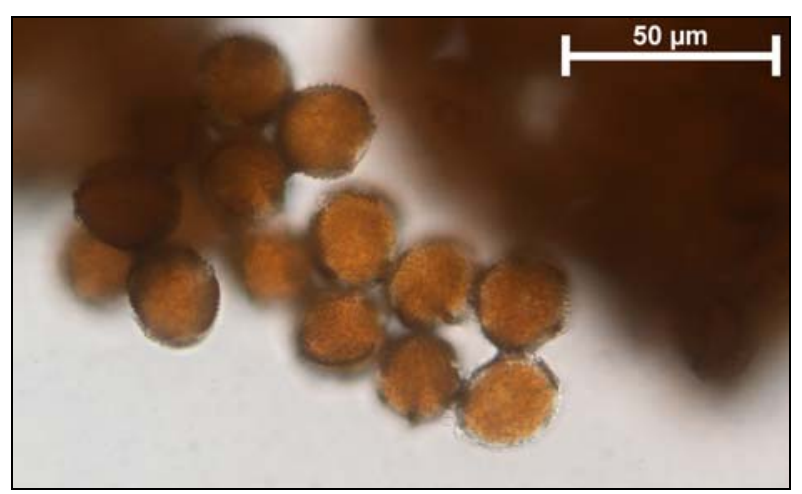

Slika 4: Eciospore so okrogle do elipsaste oblike, svetlo oranžne, $\mathrm{z}$ bradavičasto steno in povprečno merijo $23 \times 19 \mu \mathrm{m}$ 